Notre Dame Law School

NDLScholarship

Journal Articles

Publications

1983

\title{
Greatness Thrust upon Them: Class Biases in American Law
}

Robert E. Rodes

Notre Dame Law School, robert.e.rodes.1@nd.edu

Follow this and additional works at: https://scholarship.law.nd.edu/law_faculty_scholarship

Part of the Law and Society Commons

\section{Recommended Citation}

Robert E. Rodes, Greatness Thrust upon Them: Class Biases in American Law, 28 Am. J. Juris. 1 (1983).

Available at: https://scholarship.law.nd.edu/law_faculty_scholarship/860

This Article is brought to you for free and open access by the Publications at NDLScholarship. It has been accepted for inclusion in Journal Articles by an authorized administrator of NDLScholarship. For more information, please contact lawdr@nd.edu. 


\title{
GREATNESS THRUST UPON THEM* \\ Class Biases in American Law
}

\author{
ROBERT E. RODES, JR.
}

AS FOLLOWERS OF NATURAL LAW and citizens of a nominally egalitarian society, we tend to resist the concept of a class struggle. I believe that we resist it at our peril. I propose to argue here that we in fact have a dominant class in spite of our principles to the contrary, that in operation if not in intention it is an oppressor class, that we of the legal and academic professions belong to it by occupation, mindset, and lifestyle, that its oppressive position is powerfully supported by many of our legal institutions, and that if we ignore the situation we cannot avoid responsibility for it

For methodology, I will draw on two authors, the Yugoslav Milovan Dijlas and the Peruvian Gustavo Gutierrez. Djilas may be regarded as a continuator of Marx and Engels. They established the idea of a class dialectic in history. They showed how the conditions of feudal society gave rise to the bourgeoisie, who took power from the landed aristocracy and established capitalism. They showed how the conditions of bourgeois capitalism were giving rise to a proletarian class, destined to take power from the bourgeoisie and abolish capitalism. But Marx and Engels believed that when this happened class dialectic would come to an end. Djilas, in his book The New Class, ${ }^{1}$ showed that the dialectic would go right on. Proletarian power is necessarily diffused. The proletariat cannot exercise their power on a day-to-day basis because there are too many of them, and they are not adequately trained to run an industrial society. They must turn over their power to surrogates, who have the necessary technical and organizational skills. These surrogates rapidly develop class interests and class identities that sharply distinguish them from the proletariat in whose name they act. Many commentators have remarked on the takeover of socialist societies by technicians and bureaucrats, but no one else has done so with the theoretical elegance and the Marxist methology of Djilas.

Gutierrez is a Catholic priest, and author of the leading book on liberation theology. ${ }^{2} \mathrm{He}$ certainly owes something to Marxist theory,

* This article is the text of the annual Natural Law Institute Lecture for 1983. It will appear as part of the concluding chapter in a forthcoming book, Law and Liberation.

1. M. Djilas, The New Class (New York, Prager: 1957).

2. G. Gutierrez, A Theology of Liberation (Maryknoll, N.Y., Orbis 1973). 
but his perception of the class struggle seems more empirical, less theoretical than Marx's. He begins with the obvious fact that there are unjust institutions by which people are oppressed. Every such institution creates a distinction between people who are oppressed by it and have a stake in reforming or dismantling it and people who benefit from it and have a stake in leaving it intact. A cluster of such institutions affecting the same people creates a class division between people with a stake in general reform and people with a stake in the status quo.

Djilas writes about Communist countries and Gutierrez about Latin America. But their central insights offer complementary methodologies that can be used anywhere. Djilas indicates that we should examine the forms of diffused power that have grown up around our modifications of laissez-faire capitalism, and see who the surrogates are. Gutierrez indicates that we should look at our unjust institutions and see who has a stake in keeping them going. We will find that both approaches point to the same class of people.

Let us look first at the forms of diffused power underlying our political initiatives for the relief of working people. These initiatives did not bring the proletariat to power in the way Marx and Engels envisaged, but they did bring about the adoption of many proletarian agendas. It is significant that the implementation of these agendas has almost always been entrusted to administrative agencies - that is, to bureaucratic officials exercising discretionary power. It appears that the perceived need to regulate the economy in the interest of the worker requires forms of organization and expertise that cannot be brought to bear in any other way. The diffused power of the workers, operating through legislation, has fed into the concentrated power of the bureaucracy.

The same thing has happened with the direct representation of workers in the collective bargaining process. It is theoretically possible for the workers in a small plant to choose one or two of their number to negotiate with the boss, but making deals with General Motors or IBM requires organizational skills and knowledge of economics. When collective bargaining became a condition of doing business instead of a battle cry, the workers' part in it had to be turned over to people with the organizational skills and the expertise to carry it out effectivelythat is, to people who were not workers. The diffused power of union members had to feed into the concentrated power of professional leaders.

Today, the power of capital has also become diffused. The relatively simple enterprises of the first half of the nineteenth century and the convoluted trusts of the Gilded Age have turned into the conglom- 
erates and multinationals of today. Graduated income and inheritance taxes have bitten hard into private fortunes. Laser and microchip technology has replaced water power and steam. The task of launching and operating a major business now requires an assembly of capital and expertise beyond the reach of even the richest and most gifted individuals. The typical entrepreneur is no longer a person who puts up his own capital and runs his own business. He is a person who sells stock to the public and assembles a management team to run the business on behalf of the stockholders. The nominal ownership of the business by the stockholders is recognized chiefly in the lavish graphics of the reports that management mails out to them. The diffused power of capital has fed into the concentrated power of management.

This analysis in terms of diffused power, inspired by Djilas, points to a class of people, leaders in government, labor, and business, who are characterized by their organizational skills and their technical expertise, and who have more in common with each other than they have with the respective constituencies in whose name they exercise their power. Let us now turn to the more pragmatic approach inspired by Gutierrez. That calls for us to look at what is going wrong in our society, and see who has a stake in its continuing to do so.

Let us begin with poverty and unemployment. We are often told that these are complex problems, but at one level they are quite simple. People are poor because we will not spend the money to relieve them, and they are unemployed because we will not do what is necessary to put them to work. I say will not rather than cannot because it is reasonably clear that there would be enough money to relieve the poor if we did not choose to spend it on other things, and there would be enough to do to keep everyone busy if we did not choose to get it done in other ways.

What we choose to spend our money on and what we choose to do our work with is a highly sophisticated technology, ranging from MX missiles to electric can openers. We would like to see this technology providing us with full employment and a well distributed abundance. But there is no reason to suppose it will, and we intend to go on investing in it whether it does or not. Pursuing our proposed methodology, we must ask who has a stake in maintaining this level of technology regardless of its effect on the poor and the unemployed. The answer is not hard to find. It is the class of people who have the technical and organizational skills to operate the system and draw material and psychic rewards from doing so.

Examination of other things going wrong in our society leads us to the same people. Who benefits from increased levels of military spending? The people who make and operate new weapons systems. 
Who benefits from the erosion of traditional culture patterns and stable neighborhoods? People who can afford to buy the old furniture, live in the new or updated buildings, and plug into the instant communities and eclectic lifestyle of the business and professional elite. Who benefits from the erosion of community values? People who see the community as a matrix of technical achievement rather than as a source of social stability and moral support. Who benefits from the erosion of sexual standards? People who are better able to derive satisfaction from organizational and technical accomplishments than from personal relations, middle aged men who can afford to trade their wives in on expensive new models, and young people who have never had occasion to learn about deferred gratification.

We are often told that these and the other problems facing our society are complex, and that it will not do to oversimplify them. This is true in the same sense that it was true in 1860 that slavery was a complex problem and William Lloyd Garrison was oversimplifying it, or true a hundred years later that segregation was a complex problem and Martin Luther King was oversimplifying it. When we are reflecting on the complexity of our problems, we must not forget that there is a class of people who benefit from problems being perceived as complex. That is the class of people who have the intellectual and the organizational equipment to deal with complex problems. These, of course, are the same people we have seen as benefiting from the things that are going wrong. In today's American society, to perceive a problem as complex is to commit its solution to a class of people with a stake in its not being solved.

To sum up, all our different analyses, theoretical and pragmatic, point us in the direction of the same class of people, the technical and organizational elite who are running the country-and running it in great part in their own interest, as we shall see. Let us take a closer look at this class. ${ }^{3}$

They are defined for the most part by their jobs. They draw their personal satisfactions and their pay from operating a sophisticated, capital-intensive technology, from positions in self-contained and largely unaccountable organizations, from manipulative or patronizing relations with ordinary people, or from professional expertise.

Those whose jobs place them within the elite are joined by people who follow their cultural and intellectual lead. The lifestyle and the

3. While these observatins are in great part my own, many of them were built on a foundation laid by W. Whyte, The Organization Man (New York, Simon \& Schuster: 1956). 
philosophical categories dictated by the exigencies of technology and organization are attractive to a good many of our people. Others accept them through training or habit, or because they are, or seem to be, the only game in town.

The power of the class members rests on their control of organizational structures, on their expertise, and on their wealth. In exercising their power, they are generally not accountable to anyone outside their class. Organizations are set up so that everyone involved is accountable to his superior on the organization chart, and to no one else. Experts are organized in such a way as to be accountable only to their peers. Our interpretation of personal liberty is such that wealth, unless it is invested in a regulated business, is generally not accountable at all.

The wealth of the class is based on salaries and expense accountsas the wealth of the landed aristocracy was based on rents and that of the capitalist class on profits. On the whole, we are persuaded that legitimate pay differentials correspond either to the number of people supervised or to the quantum of expertise involved in the job. Members of the organizational and technical elite claim and are accorded higher salaries than other people, and the salaries grow still higher as they move up in the ranks. What their salaries will not cover their expense accounts will. I am fairly peripheral in this class, but I have made three trips to Europe with my whole family at other people's expense, and eaten innumerable dinners around the country at restaurants I could not personally afford.

The lifestyle of the elite differs from that of the rest of our people in several important ways. First, they are geographically homogeneous and culturally eclectic. They can move to any part of the country at a moment's notice and locate themselves through their Century 21 realtors in the midst of people who think and live exactly as they do. They can be comfortable without the family, neighborhood, and subcultural ties on which other Americans depend. Second, they are vigorous consumers. Their houses are full of wall to wall carpeting, sophisticated appliances, and the other things you see advertised on television. Public transportation is generally not a problem for them. Neither is health care.

Neither is crime. The places they live and their access to police protection are such that their persons are secure, and their property is secure to the extent that it is not insured. Their concern with the criminal justice system, while often serious, is more academic than other people's.

At the same time, they are better able than other people to cope with bureaucracy, public or private. They know how to fill out forms. 
They know when and how to take their business to a higher echelon. They probably know someone in the organization or know someone who does. At least, they encounter bureaucractic personnel on a basis of equality and common perceptions. They do not have the experience, common with other people, of having their affairs percolate through a series of inaccessible people and incomprehensible processes.

On the whole, they like their jobs. On the whole, work is organized in our society in such a way as to make sure they do. The moves that we regard as increasing efficiency are almost always ones that make work simpler and more repetitive in the lower echelons, more creative and challenging in the higher.

Finally, the elite are ideologically secure. They are concerned about a wide range of social problems, but they do not generally reflect on their own responsibility for the existence of those problems. Prevailing moral doctrine may caution them about how they should use their privileges, but it continually assures them that the decision is theirs to make. Our mainstream politics does not challenge their position. Rather, it insures that the grievances of the wider community against the whole class will be turned into demands for minor adjustments between its governmental and corporate wings. But radical politics does not challenge their position either. It points toward patterns of organization and technology in which they will play an even greater part than they do now.

This brings us to the law. It does not appear that Marx and Engels held, as some of their followers did, that all law is a mere instrument of the ruling class for serving its interests. They did, however, find a disconcerting number of instances in which that was in fact the way the law operated. I find an equally disconcerting number of such instances today. The ones I am bringing forward here are far from exhaustive.

In the first place, there are legal dispositions that serve the elite through mere inadvertence. We maintain in this country the illusion of a classless society, and the illusion leads us constantly to mistake class interests for the common good. Problems that are not experienced or concerns that are not felt by the elite are routinely overlooked in the formulation of public policy by judges, legislators, academics, and businessmen.

Thus, because the elite are geographically mobile and able to find similar communities wherever they go, they are very free in adopting measures that undermine the geographical stability and delicate communities on which others depend for practical and emotional support. They maintain a system of taxation that does more than any other 
legal measure since the enclosure acts to keep people from holding onto land that other people want to develop. They fund projects for turning poor people's housing into rich people's housing, and call the result urban renewal. They locate public housing and public schools with no regard either for the disruption of old communities or for the establishment of new ones. They support corporation and banking laws that let them move capital where they please, and leave people to shift for themselves.

In other cases, the relative invulnerability of the elite leads them to support legal dispositions with a rigorous theoretical consistency that the rest of the population has to pay for. They send their children to private schools, and resist on grounds of religious freedom the government subsidies that would make such schools accessible to other people. Belonging to a class that by and large produces neither victims nor suspects, they maintain a system of criminal justice that is equally baneful to both, and insist that the constitution requires them to do so. For the sake of their freedom to read Lady Chatterley's Lover, they give legal protection to a pornography industry that corrupts and exploits people most of whom have never heard of D.H. Lawrence. As Shakespeare says, "He jests at scars that never felt a wound."

In the realm of personal relations, the legal contribution of the elite has been the apotheosis of sexual choices. John Noonan has written so powerfully of the class origins of the movement for legalized abortion ${ }^{4}$ that I hesitate to add anything. But I think it is worth noting that abortion became a feminist agenda item only with the general acceptance of women into equal status within the dominant class. Before that, the main constituencies were doctors who wished to practice their profession without legal restraints and men who resisted the social and financial consequences of begetting children. The woman was most often perceived as a victim-Noonan shows that this was the original feminist perception. The victim - the dependent woman who is driven to abortion by economic or social pressures or by the irresponsibility of the father of her child-has not gone away. But the law is more interested in the independent woman who can handle the bearing and rearing of a child if she chooses, but has chosen not to. She is the one who is a member of the elite.

I suspect that other moves in the direction of legal validation of sexual choices-turning fornication, adultery, and sodomy from crimes into officially recognized alternative lifestyles-can also be attributed to the changed position of women within the elite. If you

4. J. Noonan, A Private Choice (New York, Free Press: 1979), pp. 47-68. 
read Betty Friedan's classic The Feminine Mystique, ${ }^{5}$ you will see that she envisages a man who is so wrapped up in his technical or managerial role that he cannot sustain a serious and enduring sexual relation unless the woman takes all the responsibility for keeping it going. Ms. Friedan's remedy of choice for this situation is (or was when she wrote the book) for women to embrace technical and managerial roles with the same mindless exuberance that characterizes their menfolk. For this remedy to be implemented, something had to give. What gave was sexual responsibility and commitment. What did not give was the orientation of the elite toward technical and organizational achievement at the expense of personal relations. What else did not give was the class orientation of the law.

Recent reforms in our divorce laws give further support to the interest of the elite in non-responsible sex. No-fault divorce has become in practice divorce on demand for either party. It operates, therefore, in favor of the spouse with the least psychic investment in the marriage. This is apt to be the one who has a congenial job outside the home. The abolition of alimony obviously favors the self-reliant and employable spouse over the clinging vine type. Putting the whole package together, we find that it works fairly equitably when both spouses have independent positions within the elite, but that when one does and the other does not it is devastating for the one who does not.

One more example: the legal treatment of couples who cohabit without being married. It is hard to disagree with the view that such people have obligations toward one another that the law should recognize. But there are significant issues concerning what form that recognition should take. The famous Marvin case ${ }^{6}$ putting the relationship on a contractual basis, overruled a very interesting decision of one of the California Courts of Appeals treating the relationship as a de facto marriage - that is, dealing with it as a status. ${ }^{7}$ The difference between the contract model and the status model is that the status model allows the court to protect whichever party needs protection, whereas the contract model protects the party with the strongest bargaining position. I need not tell you what class that party usually belongs to.

Many of our favorite initiatives toward law reform in recent years have reflected their class origin by presupposing that practice among

5. B. Friedan, The Feminine Mystique (New York, 1963).

6. Marvin v. Marvin, 18 Cal.3d 660, 557 P.2d 106 (1976).

7. In re Marriage of Cary, 34 Cal. App. 3d 345, 109 Cal. Rptr. 862 (1973). See also Quebec Civil Code Revision Office, Draft Civil Code 1977, Bk. 2, art. 49, 266, 338 ; Bk. 3, art. 42 for another proposed treatment of the relationship as a de facto marriage. 
enlightened members of the elite ought to be the norm for the whole society. That would seem, for instance, to be the thought behind Karl Llewellyn's reliance on current commercial standards in his drafting of the Sales article of the Uniform Commercial Code. ${ }^{8}$ Or take the Uniform Consumer Credit Code. ${ }^{9}$ Its two basic reforms were to require lenders to state clearly how much interest they were charging, and to change the usury laws so they could charge much more than before. The idea was that with higher interest rates there would be more money available for buying things, and that with borrowers fully informed the rates would not go any higher than economic conditions warranted. For the class of people who were good enough credit risks so that they could shop around for favorable rates, and who could afford to make the payments on what they bought, the Code seems to have worked out about the way it was supposed to. But it left low income families more exposed than ever to operators who sold them shoddy merchandise that they could not afford and charged them previously unheard of interest rates.

The impact of elite agendas on law reform is particularly felt in the realm of judicial and administrative procedure. What we understand by due process of law is that decision makers will have a modicum of expertise, that prescribed organizational routines will be followed in the making of decisions, and that those concerned in the process may bring to bear on it our sophisticated modern technologies for the gathering and presenting of information. Each of these requirements contributes to the control of the decision making process by the organizational and technical class-those who have the expertise, control the organizations, and know how to assemble and present the information. Emphasis on due process has characterized the period of dominance by this class in much the same way that emphasis on property and contract characterized the period of dominance by the bourgeoisie.

There is of course nothing wrong with emphasis on due process. But because the elite are sophisticated and have plenty of professional advice, they are apt to implement their procedural concerns without enough regard for whether their expedients confuse the rest of the population or put too much strain on the available professional resources. They have developed a criminal procedure that keeps public

8. R. Danzig, "A Comment on the Jurisprudence of the Uniform Commercial Code," 27 Stanford L. Rev. (1975), p. 621.

9. For examples of the literature on this subject, see Jordan \& Warren, "The Uniform Consumer Credit Code," 68 Colum. L. Rev. (1968), p. 38; Kripke, "Gesture and Reality in Consumer Credit Reform," 44 N.Y.U. L.Rev. (1969), p. 1. 
defenders too busy to handle their caseloads. They have developed a civil procedure which the Chief Justice of the United States thinks no lawyer but a specialist can handle. They have developed an administrative procedure that makes agencies often unresponsive to the people they deal with, sometimes unresponsive to common sense.

Lawyers apply to themselves a maxim, old in Cicero's time, summum jus, summa injuria-extreme law is extreme wrong. It is poignantly applicable to the procedures emerging from our pursuit of due process under the guidance of our organizational and technical elite. They are intended to secure justice, and theoretically they do. But they create in practice a machinery of power that is accessible only to people who are familiar with it and know how to manipulate it-or to those who can afford to hire such people.

Perhaps the most pervasive class bias in our legal system is the one in favor of protecting the elite against being accountable to anyone outside their own class. We have a broad range of legal dispositions shielding professionals of every kind against lay accountability, and shielding organizations, both public and private, against lateral accountability - that is, accountability that does not run straight up the organization chart.

The professionals' first line of defense against lay accountability is peer review-the principle that only a member of the same profession is competent to judge how well a professional does his job. This principle is embodied in the certification and licensing laws that govern entry into some professions and full status in most others. It is also embodied in a miscellany of other legal arrangements such as the requirement of professional testimony in malpractice cases or the standards of review in academic promotion and tenure cases. Peer review tends to displace lay accountability because there is only so much accountability possible in a given situation. Also, peer review tends to produce a uniform outlook among professionals, so that laypeople are hard put to find alternative standards against which to measure professional performance.

As long as the goals of the profession are the same as those of the wider community, peer review serves us well enough. But if we are concerned with where the whole profession is going, or whether it is giving too little, charging too much, restricting access unduly, or claiming prerogatives it does not deserve, we need some basis for imposing accountability beyond its own ranks. Our arrangements for trying malpractice suits, reviewing bills, evaluating alternative schools, and tenuring cross-disciplinary scholars all suffer from the lack of any such basis. 
The imposition of peer review is not the only way the law resists lay accountability. There are a number of cases in which it is assumed that for laypeople to second-guess professionals is bizarre, unconstitutional, or both. This assumption is reflected in the attitude of the courts toward administrative expertise and judicial discretion. It is reflected in the considerable legal support for the view that newspaper reporters and psychologists must be free to apply their own standards of confidentiality without outside interference. The current controversies over selection of books for libraries present another example of the same assumption at work. When the decision to get rid of a book or not to acquire it is challenged in court, you can be sure it was the decision of a school board or a city council, and not that of a professional librarian.

Barriers to lateral accountability are growing rapidly in both corporation law and administrative law. Statutory restrictions on what corporate management may do become more and more attenuated with each revision of the Model Business Corporation Act. At the same time, the major financial jurisdictions have put substantial roadblocks in the way of shareholders' derivative actions. The cases imposing liability for securities act violations may be an exception to the trend, but they tend to weigh more heavily on eccentric financiers and outside directors than on management.

There are also rules that shield important management decisions from the collective bargaining process. The latest word from the Supreme Court is that management need not even bargain with its employees over the closing of the plant in which they work. ${ }^{10}$ There have been a few statutes requiring employers to give advance notice before closing down, ${ }^{11}$ but these have been vigorously and usually successfully resisted as placing an intolerable burden on business.

Administrative law in recent years has also taken great strides in the direction of non-accountability. Constitutional limits on delegation of power to administrative agencies have virtually dropped out of the picture. Judicial limits on the kinds of evidence an agency may rely on are not far behind. Court review of agencies is still often vigorous, but it has been assigned a definite place in the organization chart, and only rarely does it stray.

Even in church law, the trend toward non-accountability is at work. A series of decisions culminating in the Hull Memorial case in $1969^{12}$ has left it that no church member may seek redress in court on

10. First Nat. Maint. Corp. v. N.L.R.B., 452 U.S. 666 (1981).

11. E.g., Wis. Stat. $\S 109.07$; Me. Rev. Stat. tit. 26, § 625-B.

12. Presbyterian Church in the United States v. Hull Memorial Presbyterian Church, 393 U.S. 440 (1969). 
the ground that the leaders of his church have departed from its official doctrines. The rationale of many of these cases is hard to argue with. But, whether rightly or wrongly, they add bishops, presbyteries, and synods to corporate managements and administrative agencies in the array of pyramidal organizations impenetrable from without.

All these class orientations, and particularly the institutions of nonaccountability, are powerfully supported by the current tendency to erect ideological neutrality into a legal principle. The tendency grows out of a fusion of principles favoring racial and religious neutrality with principles protecting ideological dissidents against persecution. It is reflected not only in prevailing interpretations of free speech and the like, but also in widely accepted understandings of such matters as the attorney-client relation and the social responsibilities of corporate management. The idea is that a non-empirical value judgment of any kind is inherently subjective, and cannot legitimately be imposed on anyone against his will. To impose such a judgment on a choice of library books violates freedom of the press. To impose it on sexual choices violates the right to privacy. For an attorney to impose such a judgment on his client is unethical. For a stockholder to impose it on management violates management prerogatives.

This attitude supports the elite class because it makes it impossible for anyone to criticise the way that class is running the country. Without an ideology, no layman can challenge an expert, and no outsider can challenge an organization. Empirical observation can show us that something is going wrong. But without an ideology we have no way to get around the assurance that the problem is complex, that the experts who are trying to solve it are the ones best equipped for the task, and that the organizational routines through which their expertise is being brought to bear are the right ones. Empirical observation can show us what we are accomplishing through application of technical and organizational skills. But without an ideology we cannot determine whether the accomplishment is good or bad, or whether, if good, it is worth the resources expended on it.

The philosophy behind the move toward ideological neutrality in the law has its roots in nineteenth century utilitarianism. Its role in the nineteenth century was to liquidate the inherited restrictions that held back the technical and organizational achievements of capitalist society. It serves much the same purpose today. It is the capstone of an intellectual edifice by which the whole society is subjected to the agendas of the dominant class.

In presenting this description of the dominant class in our society and the legal institutions that support its dominance, I have used the third person- "it," "they," and "them"-throughout. In fact, though, 
like it or not, I belong to it as do the academic and professional people with whom I am inextricably identified. We all have or are busy acquiring the technical and organizational skills that constitute our tickets of admission. We intend to use those skills, and it would be irresponsible for us not to. We lead or expect to lead lives of solid technical and organizational achievement, reaping appropriate material and psychic rewards. In any event, we are made very comfortable by the same economic and social system that makes other people miserable.

We are not only members of a dominant class, we are members of an oppressor class. Whatever our personal intentions, our prosperity is founded on a system that oppresses other people. We are the custodians and beneficiaries of economic, political, and legal institutions of which our fellow citizens are the victims. They are paying for our comfort. We are supported at their expense.

It follows that the liberation of the poor in our society is for us neither an academic exercise nor an exercise in disinterested benevolence. It is our own liberation from our status as oppressors.

The foundation of this liberation to my mind is the recognition that we need it. We constantly exemplify the liberationist doctrine that to ignore the class struggle is to side with the oppressor. By supposing that we live in a classless society, we are led to suppose that whatever serves people like us serves everyone in our society. The illusion of classlessness, as I have said, leads us to mistake class interests for the common good. To recover a true perception of the common good, we must learn to recognize a class interest when we see one. I hope that what I am saying here will help us to do so.

But recognizing class interests will not make them go away. We are members of an elite class because we have technical and organizational skills that other people lack. The apparatus that we are running for the rest of society is more elaborate than the rest of society needs, but if we dismantle it entirely the rest of society will starve. And unless we dismantle it entirely we will have to go on running it, and therefore will have to go on having interests different from other people's. We can and should reduce the scale of elitism in our society-say, by limiting the size of corporations and decentralizing the functions of government-but we cannot expect in the foreseeable future to get out from under our roles as members of a dominant class.

What we can expect is to mitigate the oppressive character of those roles. Here, I will have to shift personal pronouns once again. As lawyers and legal scholars, we are not only members of the dominant class, we are also the people primarily responsible for seeing justice done to all classes. To discharge that responsibility, we-that is, we of 
the legal profession-must devise ways of channeling the technical and organizational skills of the elite into the service of the common good.

To do this, we must first recover our understanding of what the common good is. To my mind, this is not as tall an order as we often suppose. I do not believe we lack a national consensus as to what is a decent, honest, and humane way to live. The trouble is that we have been led to believe that it is somehow un-American to introduce that consensus into our public life. We have been led to believe that respect for the dissident in our society requires us to keep insisting that there is no mainstream. But without a national mainstream consensus there can be no accepted understanding of the common good. And without an accepted understanding of the common good there can be no liberation of our people from the dominance of an unaccountable and self-serving elite. It is important to protect dissenters, but I believe we can do so without pretending that there is nothing to dissent from.

In other words, if we know as a people where we stand morally and ideologically, we can use the knowledge to restrain the power of the technical and organizational elite, and make the exercise of that power accountable to the wider community. It would be repetitious to sketch out a practical program for doing so. We can have the nucleus of such a program simply by reforming the situations I have already pointed out.

One last point. Some necessary reforms may reduce efficiency, productivity, per capita income, or other statistical counters devised by the elite to measure how well they are doing things without determining whether the things are worth doing. I think we must preserve a firm equanimity in the face of this possibility. We do not need all the technical and organizational achievements that these counters measure. What we need is a decent and contributing life for all our people. To say that we will fulfill this need only to the extent that it keeps our technologies and organizations intact is to have our priorities backward.

This inversion of priorities seems to be characteristic of a ruling class mindset in every period. It is natural for the ruling class to suppose that its prerogatives are based on moral imperatives, and that inconceivable disasters will ensue if its manner of organizing society is tampered with. The sufferings of other classes, if they cannot be relieved within the existing framework, must be tolerated as the inevitable side effects of a basically beneficent system. This is how the ancient Greeks and Romans (to say nothing of John C. Calhoun) felt about a system based on slavery, how the feudal aristocracy felt about a system based on skimming the top off the proceeds of subsistence 
agriculture, and how capitalists felt about a system based on property, contract, and the Iron Law of Wages-maybe some of them still do. It is not surprising that the people who run our technologies and our organizations should feel the same way about the system that is now in place.

Certainly none of us who belong to the elite is free from this class based outlook. But our religion, our profession, and our education all urge us to look beyond class interests. If we do, we should be able to see that the real moral imperative is to provide the minimum conditions for decency and usefulness for everyone in our society, and the real disaster would be failing to do this when we have the necessary resources. With that perception, we can make our legal system what our predecessors intended it to be-an instrument for doing justice to all classes; an instrument of freedom to oppressed and oppressor alike. 